\title{
Homer 1a Gates the Induction Mechanism for Endocannabinoid-Mediated Synaptic Plasticity
}

\author{
Alan M. Roloff, Garret R. Anderson, Kirill A. Martemyanov, and Stanley A. Thayer \\ Department of Pharmacology, University of Minnesota Medical School, Minneapolis, Minnesota 55455
}

At hippocampal excitatory synapses, endocannabinoids (eCBs) mediate two forms of retrograde synaptic inhibition that are induced by postsynaptic depolarization or activation of metabotropic glutamate receptors (mGluRs). The homer family of molecular scaffolds provides spatial organization to regulate postsynaptic signaling cascades, including those activated by mGluRs. Expression of the homer la (H1a) immediate-early gene produces a short homer protein that lacks the domain required for homer oligomerization, enabling it to uncouple homer assemblies. Here, we report that Hla differentially modulates two forms of eCB-mediated synaptic plasticity, depolarization-induced suppression of excitation (DSE) and metabotropic suppression of excitation (MSE). EPSCs were recorded from cultured hippocampal neurons and DSE evoked by a $15 \mathrm{~s}$ depolarization to $0 \mathrm{mV}$ and MSE evoked by a type I mGluR agonist. Expression of H1a enhanced DSE and inhibited MSE at the same synapse. Many physiologically important stimuli initiate H1a expression including brain-derived neurotrophic factor (BDNF). Treating hippocampal cultures with BDNF increased transcription of H1a and uncoupled homer 1c-GFP (green fluorescent protein) clusters. BDNF treatment blocked MSE and enhanced DSE. Thus, physiological changes in H1a expression gate the induction pathway for eCB-mediated synaptic plasticity by uncoupling mGluR from eCB production.

\section{Introduction}

The endocannabinoid (eCB) system is an important mediator of synaptic plasticity in the CNS. eCBs produced postsynaptically diffuse in a retrograde direction to act on presynaptic cannabinoid receptor $1\left(\mathrm{CB}_{1} \mathrm{R}\right)$ and inhibit neurotransmitter release (Lovinger, 2008). Production of eCBs is initiated by two distinct yet related postsynaptic mechanisms: depolarization and metabotropic receptor activation. These processes induce short-term plasticity at excitatory synapses, termed depolarization-induced suppression of excitation (DSE) or metabotropic suppression of excitation (MSE). DSE requires $\mathrm{Ca}^{2+}$ influx via voltagegated $\mathrm{Ca}^{2+}$ channels (VGCCs), which may be amplified by ryanodine-sensitive $\mathrm{Ca}^{2+}$ stores, and subsequent $\mathrm{Ca}^{2+}$ stimulated production of 2-arachydonylglycerol (2-AG) (Isokawa and Alger, 2006). Type I metabotropic glutamate receptors (mGluRs) produce MSE by activating phospholipase $C \beta$ (PLC $\beta$ ) to release diacylglycerol (DAG), which is hydrolyzed by DAG lipase (DGL) to 2-AG (Maejima et al., 2001; Straiker and Mackie, 2007).

The Homer family of postsynaptic scaffolding proteins is central to synaptic development, organization, and plasticity (Worley et al., 2007), and has been associated with neuronal disease and addiction (Szumlinski et al., 2006, 2008). Homer proteins con-

Received Sept. 16, 2009; revised Dec. 23, 2009; accepted Jan. 13, 2010.

This work was supported by National Institutes of Health Grants DA07304, DA24428, and DA11806 (S.A.T.) and DA021743 and DA026405 (K.A.M.). A.M.R. was supported by National Institute on Drug Abuse Training Grant DA07097, and G.R.A. was supported by National Institutes of Health Grant DA024944. K.A.M. was supported by a McKnight Land Grant Professorship. We thank Dr. Keqiang Xie (University of Minnesota, Minneapolis, MN) for generation of $\mathrm{H} 2 \mathrm{a}$ and $\mathrm{H} 3 \mathrm{a}$ expression constructs.

Correspondence should be addressed to Stanley A. Thayer, Department of Pharmacology, University of Minnesota, 6-120 Jackson Hall, 321 Church Street, Minneapolis, MN 55455. E-mail: sathayer@umn.edu.

D0I:10.1523/JNEUROSCI.4603-09.2010

Copyright $\odot 2010$ the authors $\quad 0270-6474 / 10 / 303072-10 \$ 15.00 / 0$ tain an N-terminal Ena/VASP homology domain 1 (EVH1 domain) that recognizes target proteins involved in eCB signaling including the following: mGluR, PLC $\beta$, ryanodine receptors (RyRs), and L-type VGCCs (Worley et al., 2007). Homer proteins couple signaling molecules in the postsynaptic density (PSD) by oligomerizing through their C-terminal coiled-coil (CC) domain and cross-linking with other structural proteins in the PSD such as Shank and PSD-95 (Tu et al., 1999). Thus, the combination of EVH1 interaction with signaling proteins and CC domain-mediated oligomerization leads to the structural and functional apposition of synaptic proteins. Three homer genes are subject to alternative splicing yielding an array of protein products (Shiraishi-Yamaguchi and Furuichi, 2007). Expression of the short homer isoform la (H1a) uncouples CC-homer structures (Xiao et al., 1998). H1a contains an EVH1 domain but lacks the CC domain, enabling it to act in a dominant-negative capacity. H1a is an immediate-early gene induced by glutamate (Sato et al., 2001), brain-derived neurotrophic factor (BDNF) (Kato et al., 2003), activation of adenylyl cyclase (Kammermeier, 2008), stimuli that induce long-term potentiation (Kato et al., 1998), and exploratory behavior (Brakeman et al., 1997). Indeed, the rapid induction and dominant-negative properties of H1a make it a powerful modulator of postsynaptic function.

Several studies suggest a link between Homer proteins and eCB signaling. Homer $2 \mathrm{a}(\mathrm{H} 2 \mathrm{a})$ properly localized the 2-AG synthetic enzyme DGL in Neuro-2a cells (Jung et al., 2007) and $\mathrm{mGluRs}$ are attached to homer scaffolds. The inhibition of eCB-mediated long-term depression (LTD) by cocaine correlated with the expression of CC-homers (Fourgeaud et al., 2004). Thus, there are intriguing hints linking homer proteins to $\mathrm{eCB}$ signaling but this putative relationship has not been fully examined. 
Here, we tested the hypothesis that $\mathrm{H} 1 \mathrm{a}$ regulates the induction of eCB-mediated synaptic plasticity. Our data indicate that $\mathrm{H} 1 \mathrm{a}$ expression suppressed metabotropic-mediated whereas it enhanced depolarization-mediated eCB production. Furthermore, treatment with BDNF elevated $\mathrm{Hla}$ levels demonstrating a physiological mechanism to regulate eCB-mediated synaptic plasticity.

\section{Materials and Methods}

Materials. DMEM and sera were purchased from Invitrogen. BDNF was obtained from R\&D Systems. Bicuculline methochloride and dihydroxyphenylglycine (DHPG) were purchased from Ascent Scientific. All other reagents were purchased from Sigma-Aldrich.

Cell culture. Rat hippocampal neurons were grown in primary culture as described previously (Pottorf et al., 2006) with minor modifications. Fetuses were removed on embryonic day 17 from maternal rats killed with $\mathrm{CO}_{2}$ under a protocol approved by the University of Minnesota Institutional Animal Care and Use Committee in accordance with the National Institutes of Health Guide for the Care and Use of Laboratory Animals. Hippocampi were dissected and placed in $\mathrm{Ca}^{2+}-$ and $\mathrm{Mg}^{2+}$ free HEPES-buffered Hanks salt solution, $\mathrm{pH}$ 7.45. HEPES-buffered Hanks salt solution was composed of the following (in mM): 20 HEPES, $137 \mathrm{NaCl}, 1.3 \mathrm{CaCl}_{2}, 0.4 \mathrm{MgSO}_{4}, 0.5 \mathrm{MgCl}_{2}, 5.0 \mathrm{KCl}, 0.4 \mathrm{KH}_{2} \mathrm{PO}_{4}, 0.6$ $\mathrm{Na}_{2} \mathrm{HPO}_{4}, 3.0 \mathrm{NaHCO}_{3}$, and 5.6 glucose. Cells were dissociated by trituration through a series of flame-narrowed Pasteur pipettes, pelleted, and resuspended in DMEM without glutamine, supplemented with 10\% fetal bovine serum and penicillin/streptomycin $(100 \mathrm{U} / \mathrm{ml}$ and $100 \mu \mathrm{g} /$ $\mathrm{ml}$, respectively). Dissociated cells then were plated at a density of 10,000-15,000 cells/dish onto $25-\mathrm{mm}$-round cover glasses precoated with Matrigel $(250 \mu \mathrm{l} ; 0.1 \mathrm{mg} / \mathrm{ml})$. Neurons were grown in a humidified atmosphere of $10 \% \mathrm{CO}_{2}$ and $90 \%$ air at $37^{\circ} \mathrm{C}$, and fed on days 1 and 6 by exchange of $75 \%$ of the media with DMEM supplemented with $10 \%$ horse serum and penicillin/streptomycin. Cells used in these experiments were cultured without mitotic inhibitors for a minimum of $11 \mathrm{~d}$.

EPSC recordings. CNQX (6-cyano-2,3-dihydroxy-7-nitroquinoxaline)sensitive EPSCs were recorded using the whole-cell configuration of the patch-clamp technique (Kouznetsova et al., 2002). Pipettes (Narishige) with open resistances of 3-5 M $\Omega$ were filled with solution that contained the following (in mM): $120 \mathrm{~K}$-gluconate, $15 \mathrm{KCl}, 6 \mathrm{MgCl}_{2}, 0.2 \mathrm{EGTA}, 10 \mathrm{HEPES}$, $5 \mathrm{Na}_{2}$ ATP, pH 7.3 with $\mathrm{KOH}, 290 \mathrm{mOsm} / \mathrm{kg}$ for DSE recordings or 113 K-gluconate, $15 \mathrm{KCl}, 6 \mathrm{MgCl}_{2}, 10 \mathrm{BAPTA}, 10 \mathrm{HEPES}, 5 \mathrm{Na}_{2} \mathrm{ATP}, 6.85 \mathrm{CaCl}_{2}$, pH $7.3(\mathrm{KOH}), 290 \mathrm{mOsm}$ for MSE experiments. Recordings were performed at room temperature $\left(22^{\circ} \mathrm{C}\right)$ in an extracellular solution that contained the following (in $\mathrm{mM}$ ): $140 \mathrm{NaCl}, 5 \mathrm{KCl}, 9 \mathrm{CaCl}_{2}, 6 \mathrm{MgCl}_{2}, 5$ glucose, 10 HEPES, 0.01 bicuculline methochloride, $0.5 \%$ BSA, pH 7.4 with $\mathrm{NaOH}$, $325 \mathrm{mOsm} / \mathrm{kg}$. Solutions were applied by a gravity-fed superfusion system. Membrane potential was held at $-70 \mathrm{mV}$ and monosynaptic EPSCs evoked with a bipolar platinum electrode (FHC) placed near a presynaptic neuron. Voltage pulses $(0.1 \mathrm{~ms})$ were applied at a fixed rate of $0.5 \mathrm{~Hz}$ using a Grass $\mathrm{S} 44$ stimulator with a SIU-5 stimulus isolation unit (Astro-Med). DSE was elicited by depolarizing the postsynaptic cell to $0 \mathrm{mV}$ for $15 \mathrm{~s}$ followed by continued recording at $0.5 \mathrm{~Hz}$. MSE was induced by superfusion of $1 \mu \mathrm{M}$ DHPG.

$\mathrm{I}_{\mathrm{Ca}}$ recordings. Whole-cell recordings of currents through VGCCs were performed using pipettes filled with the following (in $\mathrm{mM}$ ): 145 $\mathrm{CsMeSO}_{4}, 10$ HEPES, 10 BAPTA, 5 MgATP, $1 \mathrm{Na}_{2} \mathrm{GTP}$, pH 7.35 with $\mathrm{CsOH}, 315 \mathrm{mOsm} / \mathrm{kg}$. Seals were formed in the following: $140 \mathrm{NaCl}, 5$ $\mathrm{KCl}, 9 \mathrm{CaCl}_{2}, 6 \mathrm{MgCl}_{2}, 5$ glucose, 10 HEPES, pH 7.4 with $\mathrm{NaOH}, 325$ $\mathrm{mOsm} / \mathrm{kg}$, and then switched to buffer to isolate $I_{\mathrm{Ca}}$ that contained the following (in $\mathrm{mm}$ ): 143 tetraethylammonium (TEA)-Cl, $5 \mathrm{CaCl}_{2}, 1$ $\mathrm{MgCl}_{2}, 10$ HEPES, 10 glucose, $0.1 \%$ bovine serum albumin, $\mathrm{pH} 7.4$ with TEA-OH, $325 \mathrm{mOsm} / \mathrm{kg}$. Series resistance was compensated by a minimum of $75 \%$. Membrane potential was held at $-80 \mathrm{mV}$ and currents evoked by stepping to $0 \mathrm{mV}$ for $200 \mathrm{~ms}$ every $10 \mathrm{~s}(0.1 \mathrm{~Hz})$. Recordings were not corrected for leak as there was essentially no current at the $0 \mathrm{mV}$ test potential in the presence of $200 \mu \mathrm{M} \mathrm{Cd}{ }^{2+}$.

Data acquisition and analysis. Whole-cell currents were amplified using an Axopatch 200A. For EPSC and $I_{\mathrm{Ca}}$ recordings, data were filtered at 2 and $1 \mathrm{kHz}$ and digitized at 11 and $5 \mathrm{kHz}$ with a Digidata interface controlled by pClamp software (MDS Analytical Technologies), respectively. Access resistance and leak currents were monitored continuously, and the recording excluded if either changed significantly. In EPSC experiments, sweeps preceded or followed by spontaneous synaptic currents were excluded from analysis. To calculate percentage inhibition of EPSC and $I_{\mathrm{Ca}}$ amplitudes, the mean peak current from the sweeps collected during the $1 \mathrm{~min}$ preceding drug application was compared with the average peak current during the final minute of drug treatment, the time at which inhibition was maximal.

DNA constructs and transfection. The coding regions for Homer 1a and 1c were amplified by PCR from the Marathon-Ready mouse brain cDNA library (Clontech) using the $5^{\prime}$-primer ATGGGGGAGCAACCTATCTTCAGC and 3'-primer TTACTTAATCATGATTGCTGAATTG combination for Homer 1a, and the $5^{\prime}$-primer ATGGGGGAGCAACCTATCTTCAGC and 3 '-primer TTAGCTGCATTCCAGTAGCTTGGC combination for Homer 1c. PCR products were subsequently cloned into the pcDNA3.1/V5 His-TOPO vector or the pcDNA3.1/NT-GFP-TOPO vector (Invitrogen) according to manufacturer's specifications. Homer2a was amplified from human cDNA with an additional N-terminal c-myc tag using the $5^{\prime}$-primer ACAAGCTTATGGAACAAAAACTTATTTCTGAAGAAGATCTGGGAGAACAGCCCATCTT and 3'-primer CGGCCGCCTAGTTATCGGTGCCCAGCT. PCR products were subsequently cloned into pcDNA3.1 vector via the $5^{\prime}$-HindIII and $3^{\prime}$-NotI restriction digest sites. Similarly, Homer3a was PCR amplified from mouse cDNA and cloned into pcDNA3.1 using the 5 ' -primer ACAAGCTTATGGAACAAAAACTTATTTCTGAAGAAGATCTGTCCACAGCCAGGAACA and 3' -primer GCGGCCGCCTAGGGTGCTGCCTCTGCCA. All constructs were propagated in Escherichia coli Top-10 strain (Invitrogen), isolated using Maxiprep kits (QIAGEN), and sequenced.

Hippocampal neurons were transfected with plasmid DNA using the calcium phosphate procedure described by Xia et al. (1996), with some modifications. Briefly, 9-11 d after plating, hippocampal neurons were placed in serum-free DMEM ( $1 \mathrm{ml}$ per dish) supplemented with $1 \mathrm{~mm}$ sodium kynurenate, $10 \mathrm{mM} \mathrm{MgCl}_{2}$, and $5 \mathrm{~mm}$ HEPES, pH 7.5 for $30 \mathrm{~min}$. The conditioned media was saved. A DNA/calcium phosphate precipitate was prepared by mixing $3.8 \mu \mathrm{l}$ of $2 \mathrm{M} \mathrm{CaCl}_{2}, 1 \mu \mathrm{g}$ of DNA per plasmid and $\mathrm{dH}_{2} \mathrm{O}$ in a volume of $30 \mu \mathrm{l}$ with an equal volume of $2 \times$ HEPESbuffered saline (274 mM NaCl, $10 \mathrm{~mm} \mathrm{KCl}, 1.4 \mathrm{~mm} \mathrm{Na}{ }_{2} \mathrm{HPO}_{4}, 15 \mathrm{~mm}$ D-glucose, 42 mм HEPES, pH 7.05). The precipitate was allowed to form for $30 \mathrm{~min}$ at room temperature $\left(22^{\circ} \mathrm{C}\right)$ before addition to the cultures. Sixty microliters of the DNA/calcium phosphate precipitate were added dropwise to each dish. Dishes were returned to the $10 \% \mathrm{CO}_{2}$ incubator. After $1.5 \mathrm{~h}$, the incubation was stopped by washing the cells three times with $3 \mathrm{ml}$ per well of DMEM ( $10 \mathrm{~mm} \mathrm{MgCl}_{2}, 5 \mathrm{~mm}$ HEPES). The saved conditioned medium was added back to each well, and the cells were returned to a $10 \% \mathrm{CO}_{2}$ incubator at $37^{\circ} \mathrm{C}$. The transfection efficiency ranged from 2 to $11 \%$.

Quantitative real-time reverse transcription-PCR experiments. RNA was extracted from hippocampal cultures using an RNA isolation kit (Stratagene). Quantitative real-time reverse transcription-PCR (Q-RT-PCR) was performed on $100 \mathrm{ng}$ of isolated RNA using a SYBR Green Q-RT-PCR kit (Stratagene). Homer 1a primers ( $5^{\prime}$-CAAACACTGTTTATGGACTG-3' and $5^{\prime}$-TGCTGAATTGAATGTGTACC- $3^{\prime}$ ) were designed against the unique 3' mRNA end of homer 1a, not present in the long-splice isoforms of homer (i.e., homer 1c). In addition to using equal amounts of total RNA as defined by UV spectroscopy, we also included an internal reference control [glyceraldehyde-3-phosphate dehydrogenase (GAPDH)] to account for the integrity of mRNA. QuantiTect primers (QIAGEN) were used for amplification of GAPDH mRNA. PCR cycling and detection was performed on a Mx3005P PCR system, and quantitative analysis was performed with MxPro-Mx3005P software, version 4.01 (Stratagene).

Confocal microscopy. Forty-eight to $72 \mathrm{~h}$ after transfection with expression vectors for DsRed 2 and Homer $1 \mathrm{c}$ fused to green fluorescent protein (H1c-GFP) (Inoue et al., 2007), the Petri dish with cells was sealed with Parafilm and imaged with an Olympus Fluoview 300 laser-scanning confocal microscope attached to an inverted Olympus IX70 microscope equipped with a PlanApo $60 \times$ oil-immersion objective (numerical aperture, 1.40). For all experiments, an eight step ( $1 \mu \mathrm{m} / \mathrm{step}) z$-series was performed. GFP was excited at $488 \mathrm{~nm}$ with an argon laser and imaged at 
$530 \mathrm{~nm}$ (10 nm bandpass). DsRed2 was excited at $546 \mathrm{~nm}$ with a He-Ne laser and imaged at 605 $\mathrm{nm}$ (75 $\mathrm{nm}$ bandpass). Cells were returned to the incubator immediately after imaging.

Image processing. To count and label homer 1c-GFP puncta, an automated algorithm was created using MetaMorph 6.2 image processing software (Waataja et al., 2008). First, maximum $z$-projection images were created from the DsRed2 and GFP image stacks. Next, a threshold set $1 \mathrm{SD}$ above the image mean was applied to the DsRed2 image. This created a 1 bit image that was used as a mask via a logical AND function with the GFP maximum $z$-projection. A top-hat filter (80 pixels) was applied to the masked H1c-GFP image. A threshold set $1.5 \mathrm{SD}$ above the mean intensity inside the mask was then applied to the contrast enhanced image. Structures between 8 and 80 pixels $(\sim 0.37-3.12 \mu \mathrm{m}$ in diameter $)$ were counted as puncta. The structures were then dilated and superimposed on the DsRed2 maximum $z$-projection for visualization. Changes in the number of H1c-GFP puncta were presented as a percentage of the initial puncta count from the entire cell; $n$ was the number of cells, each from a separate cover glass.

All data are presented as mean \pm SE. Significance was determined using Student's $t$ test or ANOVA with Bonferroni's post test for multiple comparisons.

\section{Results}

eCBs modulate synaptic strength after postsynaptic synthesis and retrograde diffusion to act on presynaptic $\mathrm{CB}_{1}$ Rs. In hippocampus, 2-AG synthesis can be induced by activation of type I mGluRs that couple to the PLC $\beta$ cascade or by activation of VGCCs (Maejima et al., 2001; Straiker and Mackie, 2007). Elements of this pathway interact with members of the homer family of molecular scaffolds (Nakamura et al., 2004; Hwang et al., 2005). However, the level of homer interaction with the eCB pathway induced by either mGluRs or VGCCs is mostly unknown. Here, we examined the role of homer proteins in regulating $2-A G$ production at excitatory synapses between hippocampal neurons in culture. Synaptic currents were recorded from a postsynaptic neuron held at $-70 \mathrm{mV}$ using the whole-cell configuration of the patchclamp technique. EPSCs were evoked by stimulation of the presynaptic neuron with an extracellular electrode $(0.5 \mathrm{~Hz})$. MSE was induced by superfusion of the type I mGluR agonist DHPG, and DSE was evoked by a $15 \mathrm{~s}$ test pulse to $0 \mathrm{mV}$.

\section{H1a inhibits MSE}

Activation of postsynaptic mGluRs stimulates the PLC $\beta$ cascade producing 2-AG that inhibits EPSCs by activating presynaptic $\mathrm{CB}_{1}$ Rs (Fig. 1A). Application of $1 \mu \mathrm{M}$ DHPG for 2 min inhibited EPSCs by $51 \pm 4 \%(n=12)$ (Fig. $1 B, F)$. DHPG-mediated inhibition was blocked completely by preincubation with the $\mathrm{CB}_{1} \mathrm{R}$ antagonist $N$-(piperidin-1-yl)-5-(4-iodophenyl)-1-(2,4-dichloro-
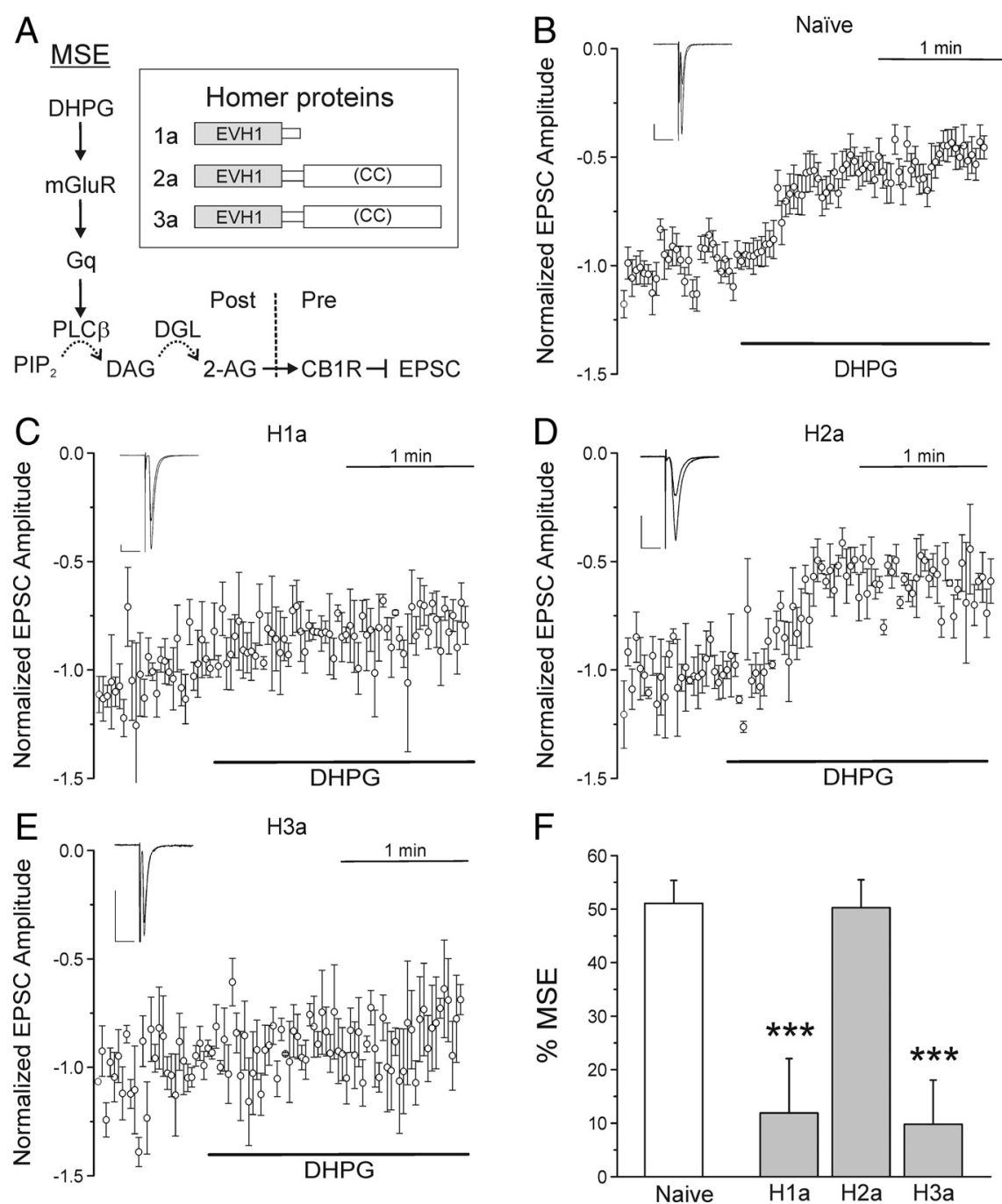

Figure 1. H1a expression inhibits MSE. $A$, Schematic representation of MSE. Activation of type I mGluRs with DHPG leads to Gq-mediated activation of PLC $\beta$. PLC $\beta$ enzymatically cleaves PIP $_{2}$ (phosphatidylinositol 4,5-bisphosphate), producing DAG. DGL hydrolyzes DAG to 2-AG. 2-AG diffuses in a retrograde direction across the synapse and inhibits EPSCs by activation of presynaptic $\mathrm{CB}_{1} \mathrm{R}$. Inset, Homer proteins used in this study. Homer proteins exist in short and long forms. The N-terminal EVH1 domain allows binding to target proteins (e.g., mGluRs, PLC $\beta$, RyRs), and the (-terminal CC domain allows oligomerization through homerhomer interactions. $\boldsymbol{B}-\boldsymbol{E}$, A bipolar concentric electrode placed near a presynaptic neuron was used to evoke EPSCs in a postsynaptic cell held at $-70 \mathrm{mV}$ in whole-cell voltage clamp. Plots show mean EPSC amplitudes versus time for naive neurons $(\boldsymbol{B})$ or those expressing $\mathrm{H1a}(\boldsymbol{C})$, H2a $(\boldsymbol{D})$, or H3a $(\boldsymbol{E})$, normalized to 30 responses immediately before DHPG application. DHPG at $1 \mu \mathrm{M}$ was applied during the time indicated by the black horizontal bars. The insets display averaged EPSCs before and 2 min after DHPG application. Calibration: Vertical, 50 pA; horizontal, 20 ms. F, Bar graph shows percentage MSE for naive neurons (open bar) and those expressing the indicated homer proteins (gray bars). Percentage MSE was calculated according to the following equation: $\% M S E=100\left(\right.$ EPSC $_{\text {control }}-$ EPSC $\left._{\text {MSE }}\right) /$ EPSC $_{\text {control}}$, where EPSC $_{\text {control }}$ is the average amplitude of the 30 EPSCs immediately before DHPG superfusion and EPSC ${ }_{\text {MSE }}$ is the average amplitude of the last 30 EPSCs during 2 min superfusion with DHPG. ${ }^{* * *} p<0.001$, $\mathrm{H} 1 \mathrm{a}$ and $\mathrm{H} 3 \mathrm{a}$ compared with naive responses. Error bars indicate SEM.

phenyl)-4-methyl-1 H-pyrazole-3-carboxamide (AM251) (300 $\mathrm{nM} ; n=3)$. Transfection of neurons with an expression construct for H1a resulted in a significant loss of DHPG-mediated inhibition to $12 \pm 10 \%$ (Fig. $1 C, F)(n=4 ; p<0.001)$. H1a, which lacks the C-terminal CC domain present in full-length members of the homer family (Fig. $1 A$, inset), is expected to uncouple type $1 \mathrm{mGluR}$ from other homer binding proteins (Xiao et al., 1998). The naive synaptic network that forms in hippocampal cultures lacks significant eCB tone, as indicated by the failure of $300 \mathrm{nM}$ AM251 to affect EPSC amplitude $(n=3)$. Similarly, $300 \mathrm{~nm}$ AM251 failed to affect EPSC amplitude in H1a-expressing cells $(n=3)$, indicating that an increase in eCB tone was not occluding a response to DHPG. In con- 
A
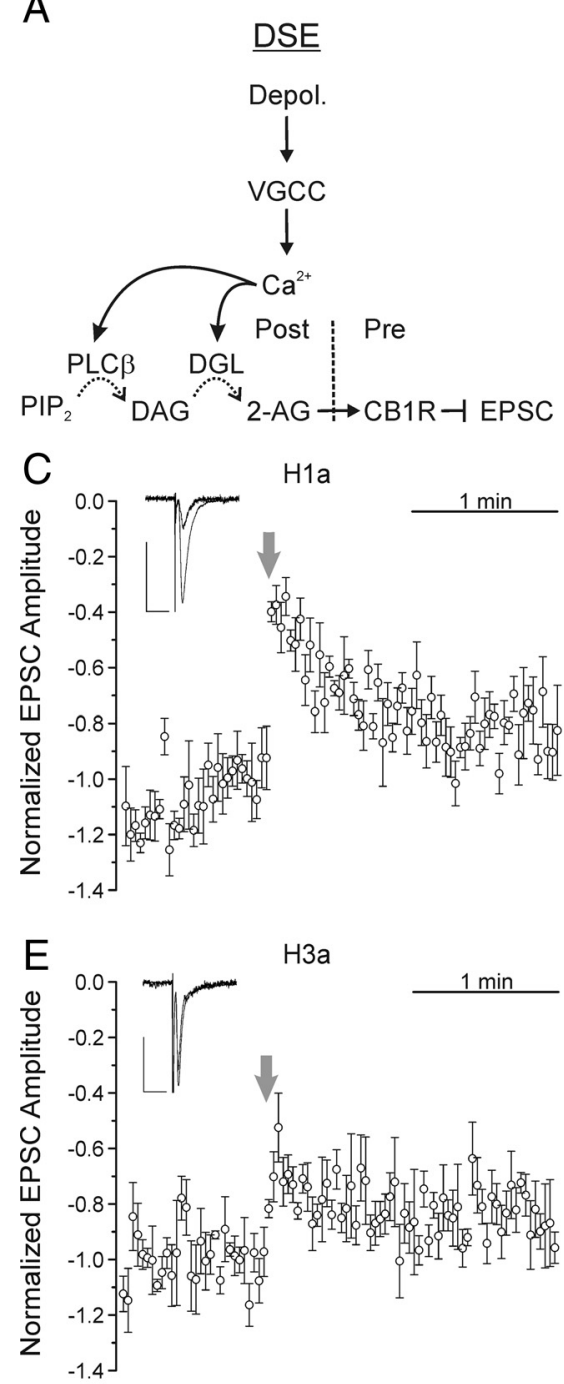
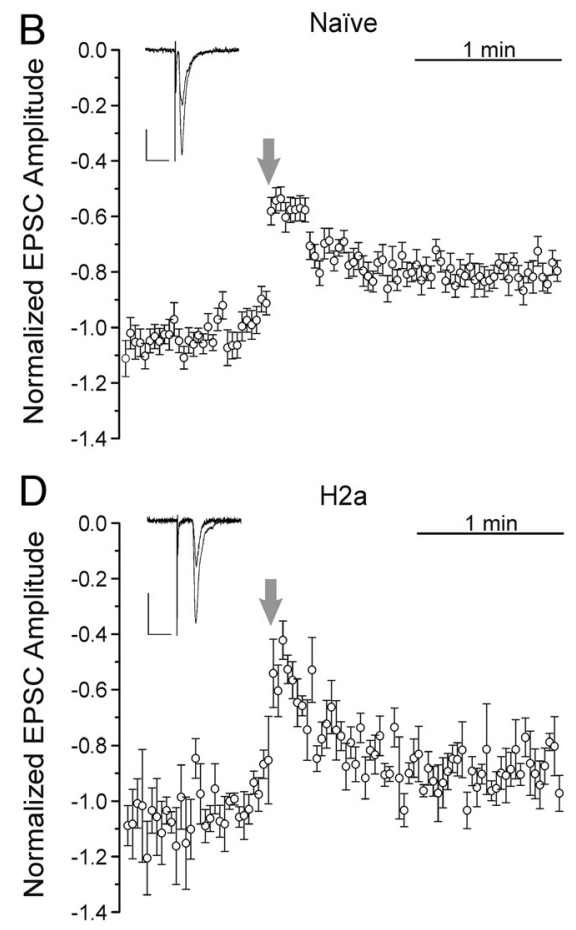

$\mathrm{F}$

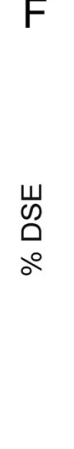

DSE would be similarly inhibited by these homer isoforms. To test this hypothesis, we induced DSE by depolarization of the patch pipette $(0 \mathrm{mV}, 15 \mathrm{~s})$ and monitored changes in EPSC amplitude. Immediately after depolarization, a transient DSE lasting 60-90s was observed with inhibition of EPSCs reaching $45 \pm 3 \%$ (Fig. $2 B, F$ ) $(n=16)$. DSE was completely blocked by pretreatment with $300 \mathrm{nM}$ AM251 $(n=3)$. Unexpectedly, expression of H1a increased the maximal depolarization-induced inhibition of EPSCs to $64 \pm 7 \%$ (Fig. 2C,F) $(n=8 ; p<0.01)$. Thus, H1a elicited an effect on DSE opposite to that observed for MSE, consistent with the idea that MSE requires a specific spatial configuration of the PLC $\beta$ signaling cascade (Fig. $1 A$ ) and that DSE is actually inhibited by long forms of homer (Fig. 2A). In Hlaexpressing cells, DSE was completely blocked by $300 \mathrm{nM} \mathrm{AM} 251(n=3)$, indicating that retrograde eCB signaling still mediated the synaptic depression. In neurons expressing $\mathrm{H} 2 \mathrm{a}$ and $\mathrm{H} 3 \mathrm{a}$, DSE behaved similar to MSE with respective inhibition of $43 \pm 8 \%$ (Fig. $2 D, F)(n=5)$ and $23 \pm 4 \%$ (Fig. $2 E, F)(n=4 ; p<$ $0.01)$. We considered the possibility that $\mathrm{H} 1 \mathrm{a}$ expression may be enhancing DSE through increased $\mathrm{Ca}^{2+}$ influx via L-type VGCCs in the postsynaptic neuron (Yamamoto et al., 2005). However, the fraction of $\mathrm{Ca}^{2+}$ current inhibited by 10 $\mu \mathrm{M}$ nimodipine was not significantly different in naive relative to $\mathrm{H} 1 \mathrm{a}$-expressing cells (42 \pm 3 and $38 \pm 6 \%$, respectively; $n=5$ ) (supplemental Fig. 1, available at www.jneurosci.org as supplemental material), suggesting that H1a-mediated enhancement of DSE occurs downstream from the VGCC. Overall, H1a expression enhanced DSE in contrast to its marked inhibition of MSE.

\section{H1a expression lowers the threshold for DSE}

The H1a-mediated enhancement of DSE suggests that H1a may lower the threshold to mobilize eCBs. To test this hypothesis,

trast to $\mathrm{H} 1 \mathrm{a}$ expression, expression of $\mathrm{H} 2 \mathrm{a}$, which contains the $\mathrm{CC}$ domain, did not change DHPG-mediated inhibition (50 $\pm 5 \%$ ) (Fig. $1 D, F)(n=3)$. Interestingly, expression of Homer 3a (H3a), which, like $\mathrm{H} 2 \mathrm{a}$, has both binding domains, also attenuated DHPGmediated inhibition of EPSCs to $10 \pm 8 \%$ (Fig. $1 E, F)(p<0.001)$. Thus, $\mathrm{H} 1 \mathrm{a}$ and $\mathrm{H} 3 \mathrm{a}$ expression interfere with mGluR-mediated $\mathrm{eCB}$ production machinery, whereas $\mathrm{H} 2$ a does not.

\section{H1a enhances DSE}

Depolarization of hippocampal neurons evokes postsynaptic $\mathrm{Ca}^{2+}$ influx via VGCCs that induces eCB synthesis (Fig. 2A) (Ohno-Shosaku et al., 2001; Wilson and Nicoll, 2001). Because expression of H1a and H3a inhibited MSE, we postulated that we conducted DSE experiments using a relatively brief (5s) depolarization of the postsynaptic neuron and compared the frequency and magnitude of DSE elicited from both naive and H1aexpressing cells (Fig. 3). Naive neurons responded sporadically to brief depolarization inhibiting EPSC amplitude in 7 of 11 trials. Naive neurons that did not display DSE had an average inhibition of $-2 \pm 4 \%$ from pre-depolarization levels (Fig. 3C) (Naive $-; n=4$ ), whereas responsive neurons exhibited DSE of $26 \pm 8 \%$ (Fig. $3 \mathrm{~A}, \mathrm{C}$ ) (Naive $+; n=7$ ). DSE elicited in H1a-expressing neurons was successful in five of five trials and led to an inhibition of $54 \pm 4 \%$ (Fig. $3 B, C)(n=5 ; p<0.05)$. Thus, the threshold stimulus required to evoke DSE was lowered in H1a-expressing neurons, suggesting that Hla enhances eCB signaling. 

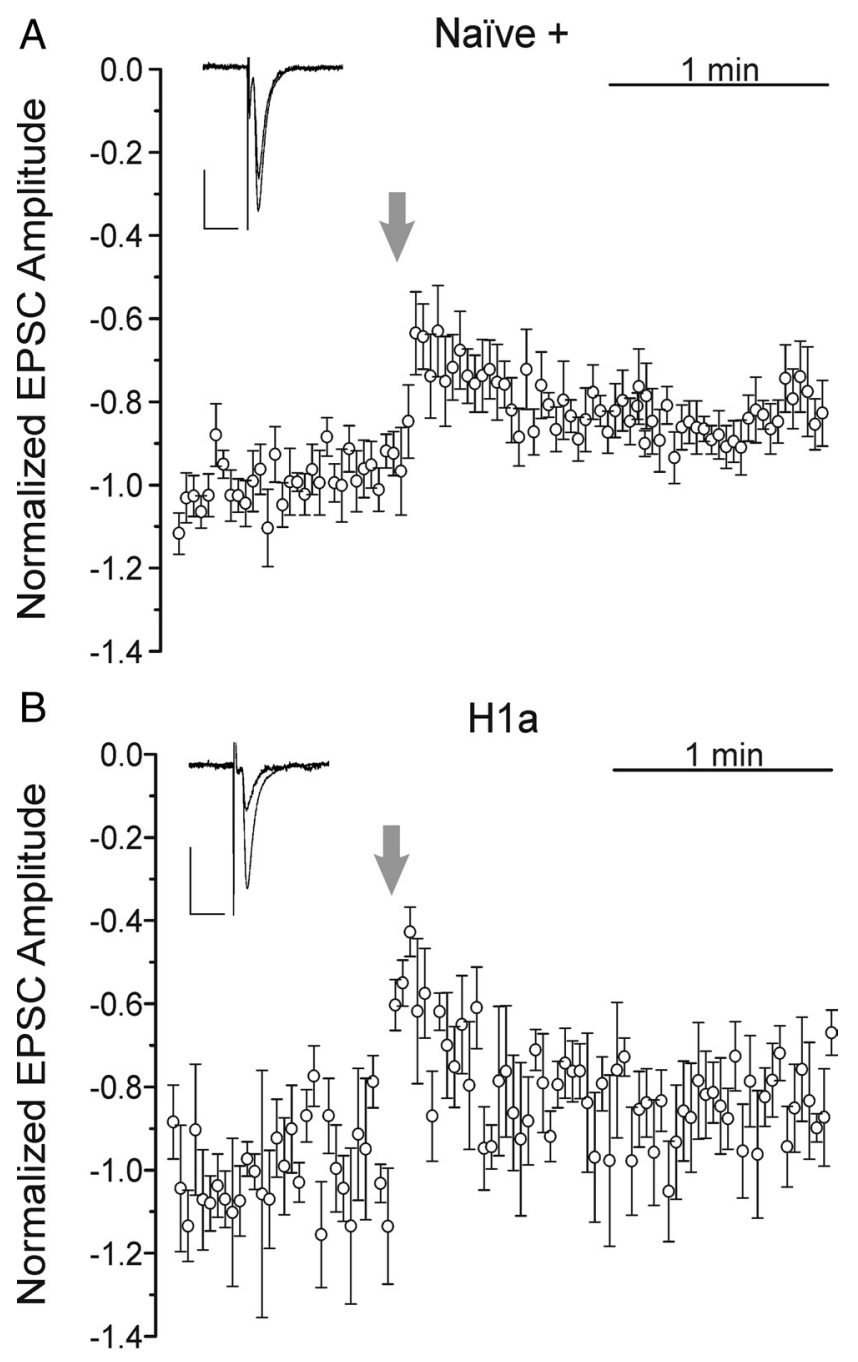

C

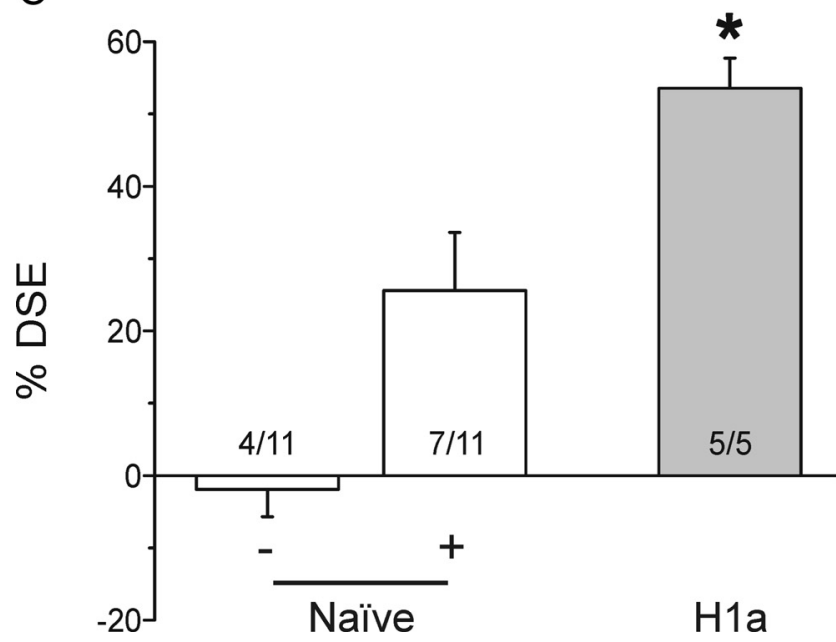

Figure 3. H1a lowers the threshold for DSE. A, B, EPSCS were evoked by stimulation of the presynaptic neuron. The postsynaptic cell was depolarized to $0 \mathrm{mV}$ for $5 \mathrm{~s}$ at the times indicated by the arrows to induce eCB production. Plots show mean EPSC amplitudes versus time for naive neurons $(\boldsymbol{A})$ or those expressing $\mathrm{H1a}(\boldsymbol{B})$ normalized to the 30 responses immediately before depolarization. The insets display averaged EPSCs from the 15 sweeps before and 3 sweeps representing maximal inhibition. Calibration: Vertical, 50 pA; horizontal, 20 ms. C, Bar graph shows the mean magnitude of DSE for naive neurons (open bars) in which DSE was absent $(-)$ or present $(+)$, and for neurons expressing $\mathrm{H} 1 \mathrm{a}$ (gray bar). Percentage DSE was calculated according to the following equation: \%DSE $=100\left(\right.$ EPSC $_{\text {control }}-$ EPSC $\left._{\text {DSE }}\right) /$ EPSC $_{\text {control, }}$, where
H1a overexpression enhances DSE while suppressing MSE in the same neuron

The hypothesis that $\mathrm{H} 1 \mathrm{a}$ enhances depolarization-induced, while suppressing mGluR-induced, production of eCBs, suggests a critical role for H1a in eCB-mediated plasticity. Thus, DSE and MSE were compared in series to verify that the H1a-induced shift in eCB signaling occurs in the same neuron. Combination experiments on naive cells yielded DSE of $42 \pm 4 \%$ with a corresponding MSE of $38 \pm 8 \%$ (Fig. $4 A, C)(n=8)$. Consistent with our hypothesis, similar experiments in $\mathrm{Hla}$-expressing cells displayed enhancement of DSE and almost complete inhibition of MSE (Fig. 4B, C). EPSCs evoked from Hla-expressing cells were inhibited by $64 \pm 13 \%$ after postsynaptic depolarization, but subsequent treatment with $1 \mu \mathrm{M}$ DHPG produced only $8 \pm 6 \%$ inhibition $(n=4 ; p<0.05)$. Thus, Hla appears capable of switching the induction mechanism for eCB signaling.

BDNF treatment increases expression of H1a, enhances DSE, and inhibits MSE

We next addressed the question of whether Hla-mediated changes in eCB signaling could be observed under more physiologically relevant conditions than those used in the preceding studies in which homer proteins were overexpressed. A number of stimuli increase $\mathrm{Hla}$ expression including BDNF (Worley et al., 2007). Indeed, BDNF increases the expression of H1a in hippocampal neurons and disperses puncta formed from homer 1c (H1c) assemblies (Sato et al., 2001; Inoue et al., 2004, 2007). In our experiments, treating hippocampal cultures with $100 \mathrm{ng} / \mathrm{ml}$ BDNF for $4 \mathrm{~h}$ enhanced transcription of Hla mRNA. Quantitative RT-PCR using $\mathrm{Hla}$ and GAPDH-specific primers revealed a $32 \pm 9$-fold induction of H1a mRNA (Fig. $5 A$ ) compared with no effect on the level of GAPDH mRNA ( $1.0 \pm 0.1$-fold; $n=3$; $p<$ $0.001)$. To determine whether BDNF stimulation of H1a mRNA leads to functional expression of the protein, we examined the dispersement of $\mathrm{H} 1 \mathrm{c}$ puncta using confocal imaging (Fig. 5B). Hippocampal cultures were cotransfected with expression vectors for DsRed2 and H1c-GFP. Cells were imaged 48-72 h after transfection using confocal imaging to identify H1c-GFP puncta (Fig. 5B). The number of fluorescent puncta was objectively counted using image processing as described in Materials and Methods. Cultures were treated with BDNF or vehicle (control) and the same cell imaged again after $4 \mathrm{~h}$. Control cells showed a $6 \pm 10 \%$ increase in the number of H1c-GFP puncta (Fig. $5 B$ ) $(n=6)$. In contrast, cells treated with BDNF for $4 \mathrm{~h}$ showed a $30 \pm 9 \%$ loss in puncta (Fig. $5 B)(n=7 ; p<0.05)$. These results confirm that BDNF treatment increases H1a transcription/ translation leading to the functional uncoupling of H1c-GFP assemblies.

To test whether treatment with BDNF shifts the balance between DSE and MSE, cells were treated for $4 \mathrm{~h}$ with $100 \mathrm{ng} / \mathrm{ml}$ BDNF and then examined in synaptic transmission experiments. After treatment with BDNF, depolarization led to a $59 \pm 7 \%$ inhibition, which is significantly greater than naive controls (Fig. $6 A, C)(n=6 ; p<0.05)$ and similar to that seen in H1atransfected neurons $(p=0.62)$. BDNF attenuated MSE produced by $1 \mu \mathrm{M}$ DHPG to $16 \pm 13 \%$, which is significantly reduced relative to naive controls (Fig. $6 B, C)(n=5 ; p<0.01)$ yet similar

EPSC $_{\text {control }}$ is the average amplitude of the 15 EPSCs immediately before depolarization and EPSC $_{\text {DSE }}$ is the average amplitude of the sweeps before and after the maximally inhibited EPSC. ${ }^{*} p<0.05$, H1a relative to naive. Error bars indicate SEM. 
A

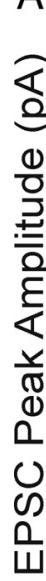

B

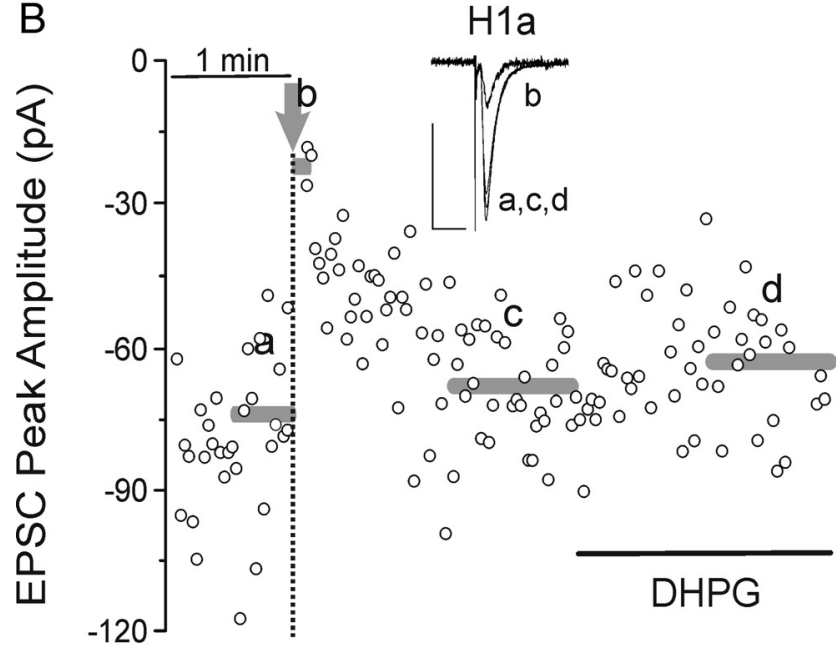

C

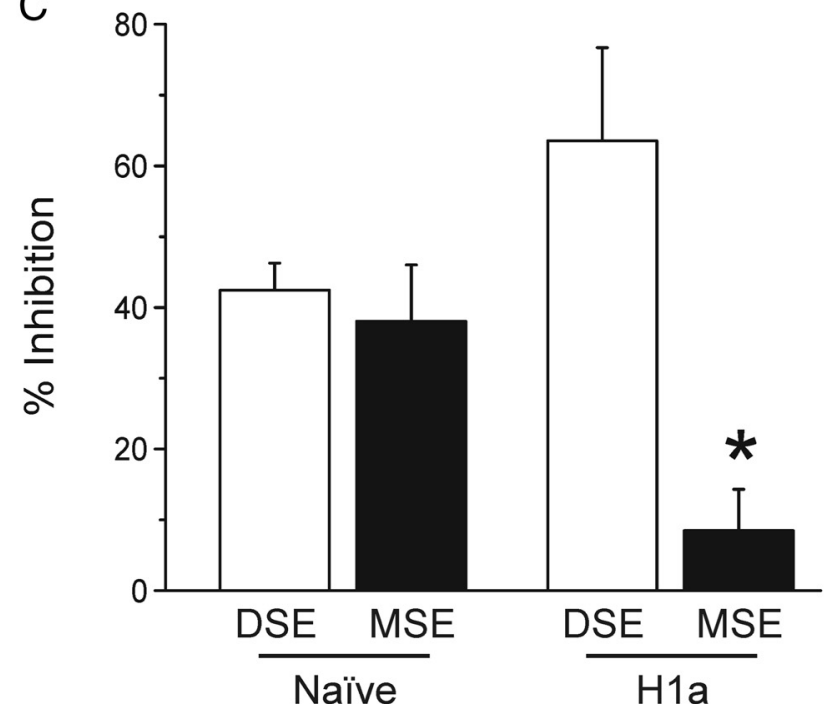

Figure 4. H1a shifts neurons toward depolarization-mediated production of eCBs. $\boldsymbol{A}, \boldsymbol{B}$, Representative plots show peak EPSC amplitude versus time for naive $(\boldsymbol{A})$ and $\mathrm{H} 1 \mathrm{a}$-expressing $(\boldsymbol{B})$ cells. Control EPSCs were evoked every $2 \mathrm{~s}(0.5 \mathrm{~Hz})$ for $1 \mathrm{~min}$. The postsynaptic cell was then depolarized to $0 \mathrm{mV}$ for $15 \mathrm{~s}$ at the times indicated by arrows. DHPG at $1 \mu \mathrm{m}$ was applied during the time indicated by the black horizontal bars. The gray bars indicate the time and amplitude of the corresponding averaged EPSCs displayed in the insets, denoted a, b, c, or d. Calibration (insets): Vertical, 50 pA; horizontal, 20 ms. C, Bar graph shows the mean magnitude of DSE (open bar) and MSE (solid bar) for naive and H1a-transfected cells. ${ }^{*} p<0.05$, homer 1a MSE versus naive MSE. Error bars indicate SEM.
A<smiles>[Li]</smiles>

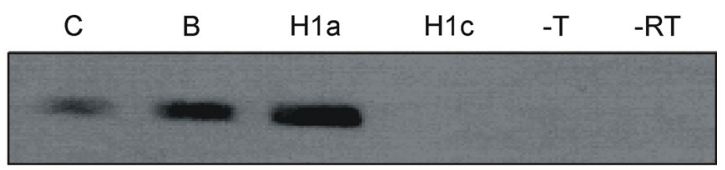

GAPDH

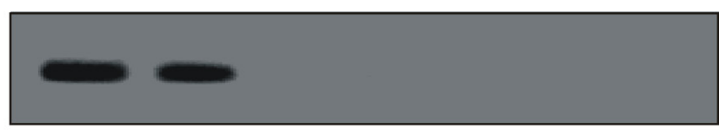

B

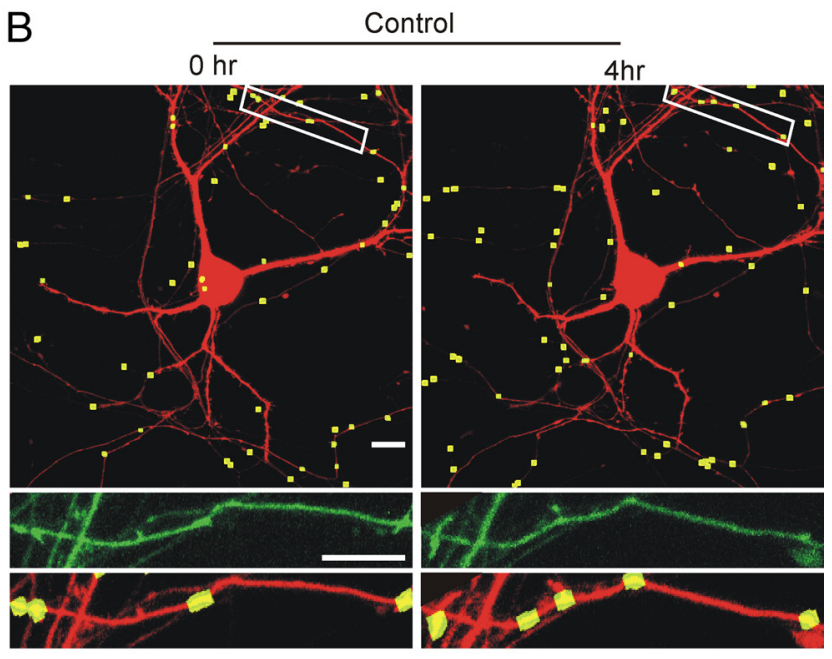

BDNF

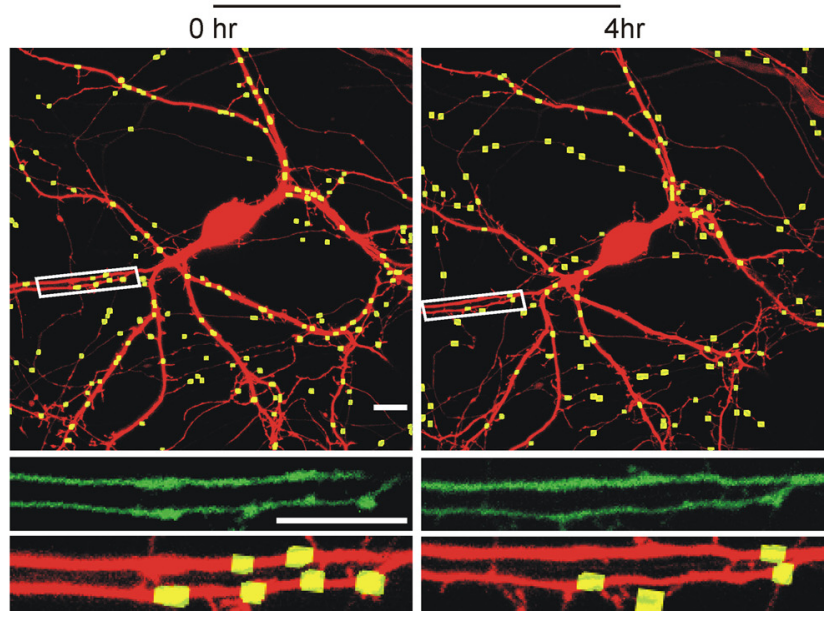

Figure 5. BDNF induces expression of H1a mRNA and disperses H1C-GFP puncta. $\boldsymbol{A}$, Hippocampal cultures were treated for $4 \mathrm{~h}$ with $100 \mathrm{ng} / \mathrm{ml}$ BDNF or vehicle control before RNA isolation and amplification by RT-PCR. Shown is gel electrophoresis of representative $P C R$ products amplified by quantitative RT-PCR from control (C) and BDNF (B)-treated cultures. Positive controls of $1 \mathrm{ng}$ of purified H1a-pcDNA3.1 plasmid (H1a), and negative controls of $1 \mathrm{ng}$ of purified H1c-pcDNA3.1 plasmid (H1c), no template $(-\mathrm{T})$, and no reverse transcriptase added to BDNF RNA (-RT). $\boldsymbol{B}$, Representative confocal images show hippocampal neurons expressing H1c-GFP and DsRed2 before $(0 \mathrm{~h})$ and after $(4 \mathrm{~h})$ treatment with vehicle (Control) or BDNF. Processed images (top) display H1c-GFP puncta (yellow) counted using the algorithm described in Materials and Methods superimposed on the DsRed 2 fluorescence image (red). Puncta counts were determined for the entire cell. Insets display the magnified image of the boxed area for unprocessed H1c-GFP image (middle) and the processed H1c-GFP/DsRed2 image (bottom). Scale bars, $10 \mu \mathrm{m}$.

to the effects observed in H1a-expressing cells ( $p=0.82$ ). These data suggest that BDNF induced $\mathrm{H} 1 \mathrm{a}$ expression that led to changes in eCB-mediated synaptic plasticity.

\section{Discussion}

Homer proteins act as molecular scaffolds in the PSD to organize signaling cascades for effective receptor activation of downstream 
A

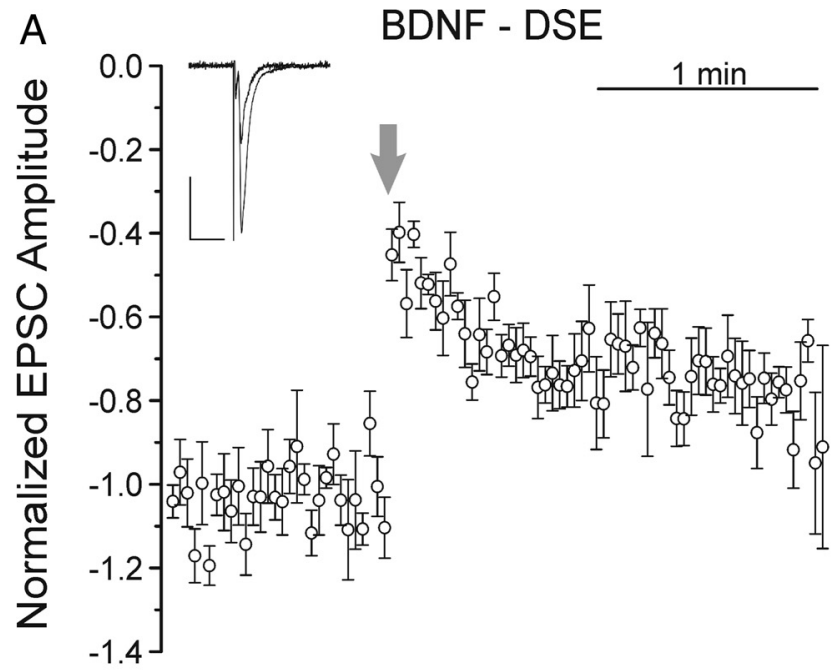

B

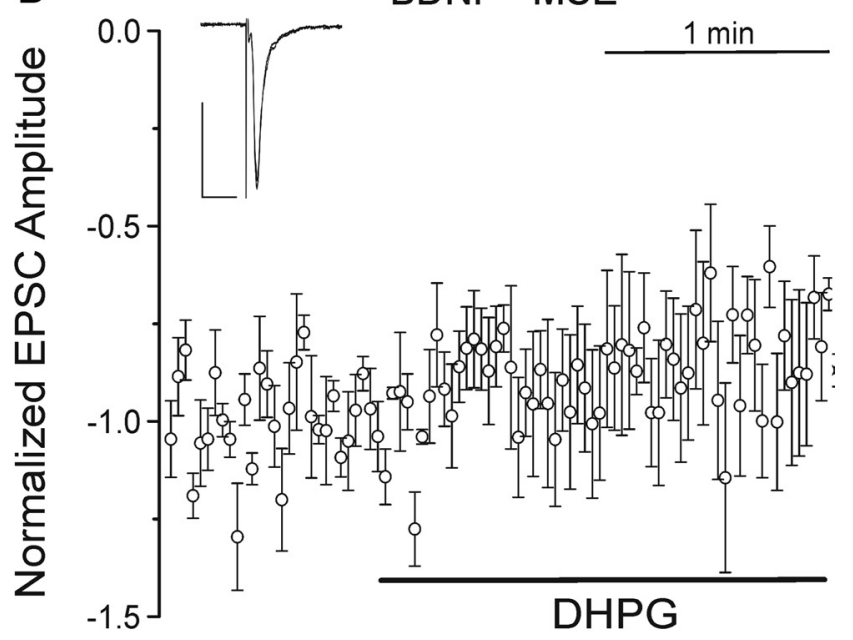

C

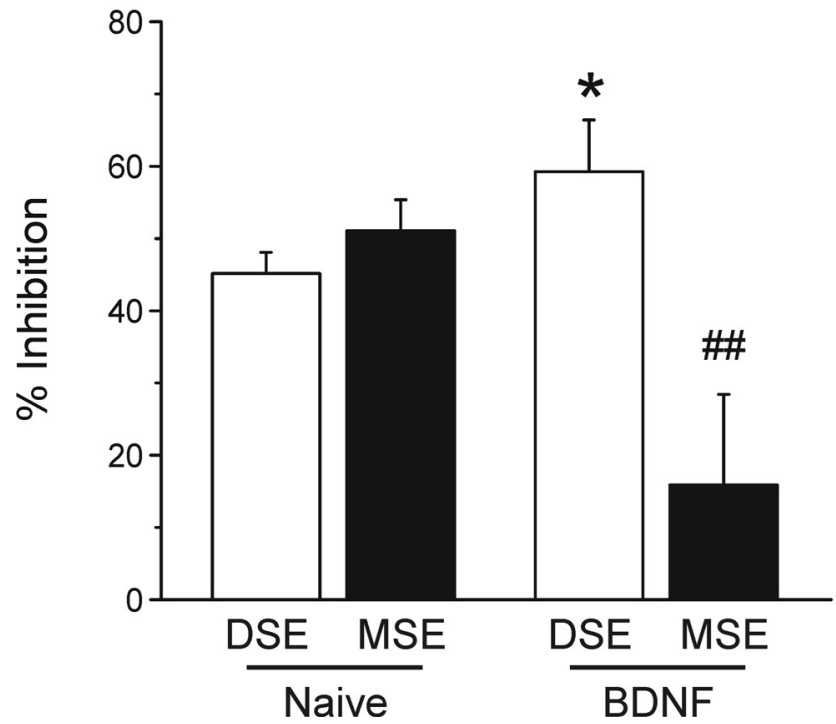

Figure 6. DSE was enhanced and MSE was inhibited in BDNF-treated neurons. $\boldsymbol{A}$, Four hour treatment with BDNF increased the magnitude of DSE. Plot shows mean EPSC amplitudes, normalized to the 30 responses immediately before depolarization plotted versus time. The postsynaptic cell was depolarized to $0 \mathrm{mV}$ for $15 \mathrm{~s}$ at the time indicated by the arrow. The inset displays 15 averaged EPSCs from before and 2 EPSCs from immediately after depolarization. Calibration (insets): Vertical, 50 pA; horizontal, 20 ms. B, BDNF treatment led to a loss of DHPG- signaling. In the current study, we show that expression of $\mathrm{Hla}$, a short isoform that disrupts homer scaffolds, modulates eCBmediated plasticity at glutamatergic synapses in hippocampal cultures. Expression of H1a lowered the stimulus threshold to evoke and enhanced the magnitude of DSE while inhibiting MSE. Treatment with BDNF enhanced the transcription of H1a mRNA and dispersed H1c-GFP puncta indicating expression of $\mathrm{H} 1 \mathrm{a}$ protein and uncoupling of CC-homer assemblies. Furthermore, BDNF produced a shift toward depolarization-mediated eCB production similar to that seen when $\mathrm{H} 1$ a was expressed. These results demonstrate that regulated expression of homer proteins provides a mechanism by which the balance between metabotropic and depolarization-induced eCB signaling may be spatially and temporally controlled.

\section{Opposite effects of H1a on DSE versus MSE}

$\mathrm{Hla}$ acts as a dominant-negative inhibitor of homer scaffolds by binding to target proteins via its EVH1 domain but, because it lacks a CC domain, fails to oligomerize with other homer proteins. Components of the eCB signaling pathway, including mGluR1a, mGluR5, PLC $\beta$, and DGL, all bind homer EVH1 domains (Jung et al., 2007; Shiraishi-Yamaguchi and Furuichi, 2007). Hla binding to type $1 \mathrm{mGluRs}$ will induce constitutive, ligand-independent activation of the receptor (Ango et al., 2001). $\mathrm{eCB}$ tone was not elevated in $\mathrm{H1a}$-expressing cells as indicated by a lack of effect of AM251 on EPSC amplitude. Furthermore, if tonic mGluR activation occluded MSE, we would have expected DSE to be inhibited as well, which was not the case. Ligandindependent activation could lead to desensitization of mGluRs uncoupling the receptors from downstream effectors. Thus, the most likely explanation for the H1a-mediated inhibition of MSE described here is an uncoupling of the type $1 \mathrm{mGluRs}$ from downstream enzymes responsible for 2-AG synthesis as a result of either receptor desensitization or disruption of the homer scaffold. A previous report outlined a critical interaction between DGL and H2a (Jung et al., 2007). Linkage through a PPxxF domain on DGL was required for effective mGluR-mediated 2-AG production but had no effect on enzymatic activity. These data are consistent with the lack of effect of $\mathrm{H} 2 \mathrm{a}$ expression on both DSE and MSE observed in our studies. Presumably, endogenous long isoforms of homer maintain the molecular assembly required for MSE but are not limiting, consistent with the expression of $\mathrm{H} 1 \mathrm{~b} / \mathrm{c}, \mathrm{H} 2 \mathrm{a} / \mathrm{b}$, and $\mathrm{H} 3 \mathrm{a} / \mathrm{b}$ in hippocampal neurons (Shiraishi et al., 2004). This reasoning would suggest that increased expression of long homer proteins should not affect MSE, but surprisingly $\mathrm{H} 3$ a expression effectively blocked MSE.

Expression of $\mathrm{H} 3 \mathrm{a}$ also attenuated DSE, suggesting a less selective interaction than that produced by Hla. Although the overall domain composition is shared between $\mathrm{H} 3 \mathrm{a}$ and $\mathrm{H} 2 \mathrm{a}$, these proteins exhibit notable differences in their amino acid sequences. Although their EVH1 domains are strongly conserved with $80 \%$ sequence identity, the CC domains vary substantially and exhibit $<30 \%$ identity. These differences are likely to produce unique preferences for interacting with various binding

$\leftarrow$

mediated MSE. The plot shows mean EPSC amplitudes normalized to the 30 responses before superfusion of $1 \mu \mathrm{M}$ DHPG, plotted versus time. DHPG was applied during the time indicated by the black horizontal bar. The insets display averaged EPSC from before and $2 \mathrm{~min}$ after DHPG application. Calibration (insets): Vertical, 50 pA; horizontal, $20 \mathrm{~ms}$. C, Bar graph shows the mean magnitude of DSE (open bar) and MSE (solid bar) for naive and BDNF treated cultures. ${ }^{*} p<0.05$, BDNF-DSE versus naive-DSE; ${ }^{\#} p<0.01$, BDNF-MSE versus naive-MSE. Error bars indicate SEM. 
partners and/or regulation by posttranslational modification, ultimately resulting in the distinct effects of the two proteins. For instance, $\mathrm{H} 3 \mathrm{a}$, but not $\mathrm{H} 2 \mathrm{a}$, was found to contain a CaMKII phosphorylation site that selectively uncouples mGluR-homerIP3R complexes (Mizutani et al., 2008). This may explain the apparent loss of MSE after H3a expression; however, other CChomers have this same site, and thus its role in $\mathrm{eCB}$ signaling is unclear.

H1a expression enhanced DSE. Thus, H1a expression does not grossly impair the 2-AG synthetic machinery. We suggest that DSE is less dependent on close apposition of VGCCs to PCL $\beta$ and DGL relative to the more constrained organization required for MSE. Because infusion of H1a into neocortical pyramidal cells upregulated L-type VGCCs (Yamamoto et al., 2005), we examined the effects of $\mathrm{Hla}$ expression on $\mathrm{Ca}^{2+}$ currents. We did not observe an increase in L-type $\mathrm{Ca}^{2+}$ currents in cells expressing $\mathrm{H} 1 \mathrm{a}$, although we note that the currents were recorded from the soma with $\mathrm{Ca}^{2+}$ chelator in the intracellular solution. Thus, we would not have observed an increased L-type $\mathrm{Ca}^{2+}$ current if the $\mathrm{H}$ la effect were limited to dendritic regions or was secondary to reduced $\mathrm{Ca}^{2+}$-dependent feedback. RyRs participate in DSE by amplifying $\mathrm{Ca}^{2+}$ influx mediated by VGCC (Isokawa and Alger, 2006). CC-homer proteins bind to and inhibit RyR function and their inhibition is reversed dose dependently by Hla (Hwang et al., 2003; Westhoff et al., 2003). Thus, it is possible that H1a reduces this inhibition resulting in enhanced $\mathrm{Ca}^{2+}$ release from intracellular stores and more efficient DSE. Alternatively, DSE is independent of PLC $\beta$ and $\mathrm{Ca}^{2+}$ stores in cerebellum (Brenowitz et al., 2006), and experiments with DGL inhibitors have yielded mixed results (Chiu and Castillo, 2008; Tanimura et al., 2009). Thus, depolarization and metabotropic receptor activation may produce eCBs by different pathways. Overall, our results demonstrate that MSE is more sensitive to H1a-induced uncoupling of homer scaffolds relative to DSE; thus, Hla can gate the induction mechanism for eCB production.

\section{Physiological consequences of H1a-regulated induction of eCB production}

The respective roles of DSE and MSE in synaptic transmission provide insight into how $\mathrm{Hla}$ modulation of $\mathrm{eCB}$ production might influence neuronal function. DSE will tend to evoke 2-AG release from the entire dendritic arbor, whereas mGluRmediated MSE is expected to be input specific (Brenowitz et al., 2006). Thus, H1a expression might potentiate the homeostatic plasticity that accompanies intense stimulation. Indeed, $\mathrm{H} 1 \mathrm{a}$ is upregulated during epileptic activity (Kato et al., 1998) and the $\mathrm{eCB}$ system is thought to provide an on-demand neuroprotection from excitotoxicity (Shen and Thayer, 1998; Marsicano et al., 2003). Clearly, this safety mechanism provides a critical defense against aberrant synaptic activity and should not be switched off. Conversely, modulating the strength of individual synapses is thought to underlie learning and memory. Indeed, $\mathrm{H} 1 \mathrm{a}$ expression is required for consolidation of long-term fear memories (Inoue et al., 2009) and H1a enters synaptic spines in an activity-dependent manner (Okada et al., 2009). Perhaps H1amediated uncoupling of mGluR-mediated MSE contributes to synaptic strengthening. Increased expression of $\mathrm{H} 1 \mathrm{a}$ lowered the stimulus threshold required to evoke DSE, suggesting that H1amediated increases in DSE might enhance on-demand neuroprotection at the expense of single synapse plasticity. The effects of viral-mediated overexpression of various homer isoforms in the hippocampus on cognitive performance and status epilepticus are consistent with this idea (Klugmann et al., 2005). H1a over- expression led to learning deficits, but increased resistance to status epilepticus, whereas $\mathrm{H} 1 \mathrm{c}$ and $\mathrm{H} 1 \mathrm{~g}$ enhanced cognitive performance, but had no effect on status epilepticus. Thus, our results demonstrating differential effects of homer long and short forms on eCB plasticity parallel complex effects observed after expression of the various isoforms in vivo.

mGluR activation has been strongly linked to changes in plasticity and behavior in part, through modulation of eCB signaling (Bortolotto et al., 1995; Diagana et al., 2002; Bellone et al., 2008). Homer proteins have also been studied in behavioral experiments. Deletion of homer genes impairs behavioral plasticity in Drosophila (Diagana et al., 2002) and mimics behaviors associated with cocaine induction and withdrawal in mice (Swanson et al., 2001; Szumlinski et al., 2004). Inhibition of eCB-mediated LTD in the nucleus accumbens after administration of cocaine was accompanied by expression of CC-homers (Fourgeaud et al., 2004). Thus, homer proteins are intimately linked to behavioral plasticity, particularly that induced by drugs of abuse, and the effects of homer proteins on the induction of the eCB system may play an integral role in behavioral modification.

Both homer proteins and eCBs participate in the remodeling of synaptic networks (Ehrengruber et al., 2004; Foa and Gasperini, 2009). H1a affects postsynaptic structures including those associated with H1c (Inoue et al., 2004) and inhibits spine morphogenesis (Sala et al., 2003). H1a is an immediate-early gene induced by several pharmacologic and activity-related stimuli (Worley et al., 2007) including BDNF, which robustly activates Hla transcription (Sato et al., 2001). We found that BDNF increased Hla mRNA and uncoupled H1c puncta found in dendritic structures. H1a induction led to enhanced DSE at the expense of MSE. BDNF plays a critical role in synaptic development, changes in synaptic strength, and the induction and adaptation to seizures (Kuczewski et al., 2009). eCBs also participate in these processes (Monory et al., 2006; Lovinger, 2008). Thus, it is reasonable to speculate that BDNF-induced, homer-mediated changes in eCB signaling contribute to dynamic changes in synaptic networks.

The H1a-mediated switch in eCB signaling may play a potentially important role in the synaptic changes that accompany drug dependence (Fourgeaud et al., 2004; Szumlinski et al., 2008), seizure disorders (Potschka et al., 2002; Marsicano et al., 2003), and learning (Heifets and Castillo, 2009; Inoue et al., 2009). This mechanism may also display regional or developmental changes. Although hippocampal neurons in culture are an established model for studying eCB signaling (Ohno-Shosaku et al., 2001; Straiker and Mackie, 2005; Roloff and Thayer, 2009) and have also been used to characterize the function of homer proteins (Sala et al., 2003; Kammermeier, 2008), in vivo studies that extend the cellular studies described here will be of considerable interest.

\section{Conclusion}

We have shown that the postsynaptic compliment of homer proteins has profound effects on both depolarization-mediated and mGluR-mediated eCB signaling. Homer-regulated changes in PSD structure provide a point of cross talk at which the diverse signals that regulate homer immediate-early gene expression can influence eCB-mediated changes in synaptic plasticity.

\section{References}

Ango F, Prézeau L, Muller T, Tu JC, Xiao B, Worley PF, Pin JP, Bockaert J, Fagni L (2001) Agonist-independent activation of metabotropic glutamate receptors by the intracellular protein Homer. Nature 411:962-965. Bellone C, Lüscher C, Mameli M (2008) Mechanisms of synaptic depression 
triggered by metabotropic glutamate receptors. Cell Mol Life Sci 65:2913-2923.

Bortolotto ZA, Bashir ZI, Davies CH, Taira T, Kaila K, Collingridge GL (1995) Studies on the role of metabotropic glutamate receptors in longterm potentiation-some methodological considerations. J Neurosci Methods 59:19-24.

Brakeman PR, Lanahan AA, O’Brien R, Roche K, Barnes CA, Huganir RL, Worley PF (1997) Homer: a protein that selectively binds metabotropic glutamate receptors. Nature 386:284-288.

Brenowitz SD, Best AR, Regehr WG (2006) Sustained elevation of dendritic calcium evokes widespread endocannabinoid release and suppression of synapses onto cerebellar Purkinje cells. J Neurosci 26:6841-6850.

Chiu CQ, Castillo PE (2008) Input-specific plasticity at excitatory synapses mediated by endocannabinoids in the dentate gyrus. Neuropharmacology $54: 68-78$.

Diagana TT, Thomas U, Prokopenko SN, Xiao B, Worley PF, Thomas JB (2002) Mutation of Drosophila homer disrupts control of locomotor activity and behavioral plasticity. J Neurosci 22:428-436.

Ehrengruber MU, Kato A, Inokuchi K, Hennou S (2004) Homer/Vesl proteins and their roles in CNS neurons. Mol Neurobiol 29:213-227.

Foa L, Gasperini R (2009) Developmental roles for Homer: more than just a pretty scaffold. J Neurochem 108:1-10.

Fourgeaud L, Mato S, Bouchet D, Hémar A, Worley PF, Manzoni OJ (2004) A single in vivo exposure to cocaine abolishes endocannabinoid-mediated long-term depression in the nucleus accumbens. J Neurosci 24:6939-6945.

Heifets BD, Castillo PE (2009) Endocannabinoid signaling and long-term synaptic plasticity. Annu Rev Physiol 71:283-306.

Hwang JI, Kim HS, Lee JR, Kim E, Ryu SH, Suh PG (2005) The interaction of phospholipase C-beta3 with Shank2 regulates mGluR-mediated calcium signal. J Biol Chem 280:12467-12473.

Hwang SY, Wei J, Westhoff JH, Duncan RS, Ozawa F, Volpe P, Inokuchi K, Koulen P (2003) Differential functional interaction of two Vesl/Homer protein isoforms with ryanodine receptor type 1: a novel mechanism for control of intracellular calcium signaling. Cell Calcium 34:177-184.

Inoue N, Nakao H, Migishima R, Hino T, Matsui M, Hayashi F, Nakao K, Manabe T, Aiba A, Inokuchi K (2009) Requirement of the immediate early gene vesl-1S/homer-1a for fear memory formation. Mol Brain 2:7.

Inoue $\mathrm{Y}$, Honkura N, Kato A, Ogawa S, Udo H, Inokuchi K, Sugiyama H, Ogawa S (2004) Activity-inducible protein Homerla/Vesl-1S promotes redistribution of postsynaptic protein Homer1c/Vesl-1L in cultured rat hippocampal neurons. Neurosci Lett 354:143-147.

Inoue Y, Udo H, Inokuchi K, Sugiyama H (2007) Homerla regulates the activity-induced remodeling of synaptic structures in cultured hippocampal neurons. Neuroscience 150:841-852.

Isokawa M, Alger BE (2006) Ryanodine receptor regulates endogenous cannabinoid mobilization in the hippocampus. J Neurophysiol 95:3001-3011.

Jung KM, Astarita G, Zhu C, Wallace M, Mackie K, Piomelli D (2007) A key role for diacylglycerol lipase- $\alpha$ in metabotropic glutamate receptordependent endocannabinoid mobilization. Mol Pharmacol 72:612-621.

Kammermeier PJ (2008) Endogenous Homer proteins regulate metabotropic glutamate receptor signaling in neurons. J Neurosci 28:8560-8567.

Kato A, Ozawa F, Saitoh Y, Fukazawa Y, Sugiyama H, Inokuchi K (1998) Novel members of the Vesl/Homer family of PDZ proteins that bind metabotropic glutamate receptors. J Biol Chem 273:23969-23975.

Kato A, Fukazawa Y, Ozawa F, Inokuchi K, Sugiyama H (2003) Activation of ERK cascade promotes accumulation of Vesl-1S/Homer-1a immunoreactivity at synapses. Brain Res Mol Brain Res 118:33-44.

Klugmann M, Symes CW, Leichtlein CB, Klaussner BK, Dunning J, Fong D, Young D, During MJ (2005) AAV-mediated hippocampal expression of short and long Homer 1 proteins differentially affect cognition and seizure activity in adult rats. Mol Cell Neurosci 28:347-360.

Kouznetsova M, Kelley B, Shen M, Thayer SA (2002) Desensitization of cannabinoid-mediated presynaptic inhibition of neurotransmission between rat hippocampal neurons in culture. Mol Pharmacol 61:477-485.

Kuczewski N, Porcher C, Lessmann V, Medina I, Gaiarsa JL (2009) Activitydependent dendritic release of BDNF and biological consequences. Mol Neurobiol 39:37-49.

Lovinger DM (2008) Presynaptic modulation by endocannabinoids. Handb Exp Pharmacol 184:435-477.

Maejima T, Hashimoto K, Yoshida T, Aiba A, Kano M (2001) Presynaptic inhibition caused by retrograde signal from metabotropic glutamate to cannabinoid receptors. Neuron 31:463-475.

Marsicano G, Goodenough S, Monory K, Hermann H, Eder M, Cannich A, Azad SC, Cascio MG, Gutiérrez SO, van der Stelt M, López-Rodriguez ML, Casanova E, Schütz G, Zieglgänsberger W, Di Marzo V, Behl C, Lutz B (2003) CB1 cannabinoid receptors and on-demand defense against excitotoxicity. Science 302:84-88.

Mizutani A, Kuroda Y, Futatsugi A, Furuichi T, Mikoshiba K (2008) Phosphorylation of Homer3 by calcium/calmodulin-dependent kinase II regulates a coupling state of its target molecules in Purkinje cells. J Neurosci 28:5369-5382.

Monory K, Massa F, Egertová M, Eder M, Blaudzun H, Westenbroek R, Kelsch W, Jacob W, Marsch R, Ekker M, Long J, Rubenstein JL, Goebbels S, Nave KA, During M, Klugmann M, Wölfel B, Dodt HU, Zieglgänsberger W, Wotjak CT, et al. (2006) The endocannabinoid system controls key epileptogenic circuits in the hippocampus. Neuron 51:455-466.

Nakamura M, Sato K, Fukaya M, Araishi K, Aiba A, Kano M, Watanabe M (2004) Signaling complex formation of phospholipase Cbeta4 with metabotropic glutamate receptor type lalpha and 1,4,5-trisphosphate receptor at the perisynapse and endoplasmic reticulum in the mouse brain. Eur J Neurosci 20:2929-2944.

Ohno-Shosaku T, Maejima T, Kano M (2001) Endogenous cannabinoids mediate retrograde signals from depolarized postsynaptic neurons to presynaptic terminals. Neuron 29:729-738.

Okada D, Ozawa F, Inokuchi K (2009) Input-specific spine entry of somaderived Vesl-1S protein conforms to synaptic tagging. Science 324:904-909.

Potschka H, Krupp E, Ebert U, Gümbel C, Leichtlein C, Lorch B, Pickert A, Kramps S, Young K, Grüne U, Keller A, Welschof M, Vogt G, Xiao B, Worley PF, Löscher W, Hiemisch H (2002) Kindling-induced overexpression of Homer 1A and its functional implications for epileptogenesis. Eur J Neurosci 16:2157-2165.

Pottorf WJ 2nd, Johanns TM, Derrington SM, Strehler EE, Enyedi A, Thayer SA (2006) Glutamate-induced protease-mediated loss of plasma membrane Ca pump activity in rat hippocampal neurons. J Neurochem 98:1646-1656.

Roloff AM, Thayer SA (2009) Modulation of excitatory synaptic transmission by Delta 9-tetrahydrocannabinol switches from agonist to antagonist depending on firing rate. Mol Pharmacol 75:892-900.

Sala C, Futai K, Yamamoto K, Worley PF, Hayashi Y, Sheng M (2003) Inhibition of dendritic spine morphogenesis and synaptic transmission by activity-inducible protein Homerla. J Neurosci 23:6327-6337.

Sato M, Suzuki K, Nakanishi S (2001) NMDA receptor stimulation and brain-derived neurotrophic factor upregulate homer la mRNA via the mitogen-activated protein kinase cascade in cultured cerebellar granule cells. J Neurosci 21:3797-3805.

Shen M, Thayer SA (1998) Cannabinoid receptor agonists protect cultured rat hippocampal neurons from excitotoxicity. Mol Pharmacol 54:459-462.

Shiraishi Y, Mizutani A, Yuasa S, Mikoshiba K, Furuichi T (2004) Differential expression of Homer family proteins in the developing mouse brain. J Comp Neurol 473:582-599.

Shiraishi-Yamaguchi Y, Furuichi T (2007) The Homer family proteins. Genome Biol 8:206.

Straiker A, Mackie K (2005) Depolarization-induced suppression of excitation in murine autaptic hippocampal neurones. J Physiol 569:501-517.

Straiker A, Mackie K (2007) Metabotropic suppression of excitation in autaptic hippocampal neurons. J Physiol 578:773-785.

Swanson CJ, Baker DA, Carson D, Worley PF, Kalivas PW (2001) Repeated cocaine administration attenuates group I metabotropic glutamate receptor-mediated glutamate release and behavioral activation: a potential role for Homer. J Neurosci 21:9043-9052.

Szumlinski KK, Dehoff MH, Kang SH, Frys KA, Lominac KD, Klugmann M, Rohrer J, Griffin W 3rd, Toda S, Champtiaux NP, Berry T, Tu JC, Shealy SE, During MJ, Middaugh LD, Worley PF, Kalivas PW (2004) Homer proteins regulate sensitivity to cocaine. Neuron 43:401-413.

Szumlinski KK, Kalivas PW, Worley PF (2006) Homer proteins: implications for neuropsychiatric disorders. Curr Opin Neurobiol 16:251-257.

Szumlinski KK, Ary AW, Lominac KD (2008) Homers regulate druginduced neuroplasticity: implications for addiction. Biochem Pharmacol 75:112-133. 
Tanimura A, Kawata S, Hashimoto K, Kano M (2009) Not glutamate but endocannabinoids mediate retrograde suppression of cerebellar parallel fiber to Purkinje cell synaptic transmission in young adult rodents. Neuropharmacology 57:157-163.

Tu JC, Xiao B, Naisbitt S, Yuan JP, Petralia RS, Brakeman P, Doan A, Aakalu VK, Lanahan AA, Sheng M, Worley PF (1999) Coupling of mGluR/ Homer and PSD-95 complexes by the Shank family of postsynaptic density proteins. Neuron 23:583-592.

Waataja JJ, Kim HJ, Roloff AM, Thayer SA (2008) Excitotoxic loss of postsynaptic sites is distinct temporally and mechanistically from neuronal death. J Neurochem 104:364-375.

Westhoff JH, Hwang SY, Duncan RS, Ozawa F, Volpe P, Inokuchi K, Koulen P (2003) Vesl/Homer proteins regulate ryanodine receptor type 2 function and intracellular calcium signaling. Cell Calcium 34:261-269.
Wilson RI, Nicoll RA (2001) Endogenous cannabinoids mediate retrograde signalling at hippocampal synapses. Nature 410:588-592.

Worley PF, Zeng W, Huang G, Kim JY, Shin DM, Kim MS, Yuan JP, Kiselyov $\mathrm{K}$, Muallem S (2007) Homer proteins in $\mathrm{Ca}^{2+}$ signaling by excitable and non-excitable cells. Cell Calcium 42:363-371.

Xia Z, Dudek H, Miranti CK, Greenberg ME (1996) Calcium influx via the NMDA receptor induces immediate-early gene transcription by a MAP kinase/ERK-dependent mechanism. J Neurosci 16:5425-5436.

Xiao B, Tu JC, Petralia RS, Yuan JP, Doan A, Breder CD, Ruggiero A, Lanahan AA, Wenthold RJ, Worley PF (1998) Homer regulates the association of group 1 metabotropic glutamate receptors with multivalent complexes of homer-related, synaptic proteins. Neuron 21:707-716.

Yamamoto K, Sakagami Y, Sugiura S, Inokuchi K, Shimohama S, Kato N (2005) Homer la enhances spike-induced calcium influx via L-type calcium channels in neocortex pyramidal cells. Eur J Neurosci 22:1338-1348. 